Volume 7, Issue 3, 583 - 589.

ISSN: 2165-8714

http://www.eu-jer.com/

\title{
The Relationship between Resilience and Constant Hope in Students Studying Sports Science *
}

\author{
Osman Tolga Togo \\ Harran University, TURKEY
}

\author{
Cagdas Caz ${ }^{* *}$ \\ Yozgat Bozok University, TURKEY
}

\author{
Recep Fatih Kayhan \\ Recep Tayyip Erdogan University, \\ TURKEY
}

Received: May 9, 2018 - Revised: June 21, 2017 - Accepted: June 29, 2018

\begin{abstract}
Individuals face negative events throughout their lives and such events can cause problems in every aspect of life. A high level of resilience is required to cope with such negative events. There are various factors that affect resilience. Hope is one of those factors. This factor provides a strong structure to individuals and keeps identified objectives alive. Based on this view, the aim of this study was to investigate the relationship between resilience and constant hope of students studying in a sports science department. Accordingly, the study group of this study consisted of 203 students with 91 female and 112 male students studying in a sports science faculty/school of physical education and sports of universities. The data collection tools of this study were the "Resilience Scale" and the "Constant Hope Scale". Additionally, to collect information about the students, the "Personal Information Form" developed by the researchers was adopted during the data collection process. The analysis of the obtained data was done with descriptive statistics, t-test for independent two groups, one- way variance analysis (Anova), and Pearson Correlation. To determine which groups caused the statistical difference after one-way variance analysis (Anova), the Tukey HSD multiple comparative test was applied. The results of the study indicated that the data obtained on a scale basis had normal distribution. While there was no significant difference for gender between the relationship of resilience and constant hope, there was a statistically significant difference between different age groups. Additionally, the correlation analysis indicated that there was a positive, moderate level relationship between the two scales.
\end{abstract}

Keywords: Sports science, constant hope, resilience.

To cite this article: Togo, O. T., Caz, C., \& Kayhan, R. F. (2018). The relationship between resilience and constant hope in students studying sports science. European Journal of Educational Research, 6(4), 583-589. doi: 10.12973/eu-jer.7.3.583

\section{Introduction}

Sports research in recent years has emphasized assessment of applications, such as enhancing the mental health of sports players, preventing possible problems, increasing performance, and the well-being of counselees. Various researchers were intrigued by how individuals in education, sports, and life are able to stand strong against the problems in life and how they are able to cope with such problems. Psychological consultants, sports psychologists, mentors, and experts in psychology have stated that individuals will become stronger as they overcome such negative events. This situation was described using the concepts of resilience and strength.

Resilience is a relatively new research area in Turkey, initially arising in early 2000 . The literature uses different terms such as "indomitableness" (Ogulmus, 2001), "resilience" and "strength to recuperate" (Terzi, 2005). Resilience is used as a structure that references positive adaptation against disaster, stress, or trauma (Masten, 2001). Fraser, Richman, and Galinsky (1999) defined resilience as achieving positive and unexpected success under harsh conditions and adapting to unique conditions and events. As it is clearly stated, the literature has different definitions of resilience. In these definitions, resilience was defined as sustaining life and displaying psychological competence when faced with negative events with traumatic results (Staudinger, Marsiske and Baltes, 1993; Yu and Zhang, 2007) or the strength to recover (Terzi, 2008). On the other hand, other definitions include the ability to achieve positive and unexpected success under harsh conditions and adapt to unique conditions and events.

In reviewing the related literature, it is clear that in addition to increasing the physical resilience of athletes, protective factors that support resilience have positive effects. Gilligan (1999) stated that in addition to social and cultural activities, sports activities had an important effect on developing resilience in young people. Martinek and Hellison (1997) stated that physical activity and sports are suitable tools to develop resilience among youth, and these tools will

\footnotetext{
${ }^{*}$ Abstract of this study was submitted as oral paper in World Sport Science Research Convention (23-26 November 2017, Manisa).

** Corresponding author:

Cagdas Caz, Yozgat Bozok University, School of Physical Education and Sports, Turkey.

Email: cazcagdas@gmail.com
} 
develop social competence and autonomy, and provide hope and optimism. There are numerous concepts that have effects on resilience. These concepts are given in the literature as playing sports, engaging in physical activity, being subjected to stress, and hoping.

In this sense, constant hope -which is another concept of this study-has an important effect on individual mental and physical health (Frankl, 2000), well-being (Tsukasa and Snyder, 2005), life satisfaction (Bailey and Snyder, 2007; Cole, 2008), motivation levels (Snyder, Lapointe, Crowson and Early, 1998), self-sufficiency (Snyder, 2002), and life quality (Miller, 2007). According to Staats and Stassen (1985), hope is dominance of positive future expectations over negative future expectations. Hope is intrinsic and has a soothing effect (Bloch, 2007). Additionally, hope is a fundamental humanitarian status that contains individual ideas about belief and trust in the world, and that life is worth living. Hope is a good indicator that positive emotions have positive effects on development and well-being (Fredrickson, 2001). Many theorists emphasize developing and supporting aspects of positive emotions (Cacioppo, Gardner and Berntson, 1999; Carver and Scheier, 1990). Positive emotions enhance a variety of emotions, ideas, and behaviors. Additionally, it contributes to the individual adaptation of the individual to new conditions by strengthening physical and psychological accumulation. A high number of positive emotions can affect the development of quick recovery from stressful events. Additionally, it gives motivation strength to individuals (Frederickson, 2001).

The basis of sports is constantly desiring success, and to continue moving forward when faced with difficulties. Athletes continue to work with the hope of achieving targets. To provide consistency, physical conditions, resilience, and hope levels of athletes are important concepts. It is believed that identifying status of these concepts and providing relationship among these concepts can have an effect on the success of athletes. Furthermore, when the related literature was reviewed, there was no study that evaluated resilience and constant hope concepts together. In addition to various known benefits of sports, it is true that sports has a positive effect on individual resilience and hope level. Since this study was conducted on students studying in the sports science field, this study is important to determine the relationships between sports and related concepts, and to contribute to the literature regarding resilience, and constant hope.

Based on this view, the aim of the study was to reflect resilience and constant hope status of students who identify as athletes and who study sports science, and to determine the relationship between these conditions. For this purpose, answers to certain questions will be investigated: (1) What are the resilience and constant hope levels of students studying in sports science field? (2) Is there a significant difference between resilience and constant hope for gender of students studying in the sports science field? (3) Is there a significant difference between resilience and constant hope for age of students studying in sports science field? (4) Is there a significant difference between resilience and constant hope of students studying in sports science field?

\section{Methodology}

\section{Study Group}

The study group of this study consisted of a total of 203 students with 91 females and 112 male students studying in a sports science faculty/school of physical education and sports of universities.

\section{Data Collection Tools}

The data collection tools of this study was selected as "Resilience Scale" developed by Smith et al. (2008) and tested for verification-reliable in Turkish by Dogan (2015), and "Constant Hope Scale" developed by Snyder et al. (1996) and adapted to Turkish by Tarhan and Bacanli (2015), and the "Personal Information Form" developed by researchers.

The "Resilience Scale" developed to measure resilience of individuals consisted of 6 items and single-factor structure. The scale is a 5-point Likert type with (1) Completely Inconvenient (2) Inconvenient (3) Slightly Convenient (4) Convenient, and (5) Completely Convenient.

The "Constant Hope Scale" developed to determine constant hope levels of individual older than fifteen years old consisted of 12 items and two sub-dimensions. Sub-dimensions were Alternative Way Idea, and Actuator Idea, and were measured by four items each. Among these four items, one represented past, two represented current conditions, and one represented future. Other four items were fill items unrelated with hope (Tarhan and Bacanli, 2015, 5). The scale was 8-point Likert type with (1) Completely False, (8) Completely True.

\section{Data Collection}

Data was collected via an online form created using Google in 2017 years. Researchers sent the link of the form to students in the study via social media, and e-mail. Explanatory information regarding the study was given on the upper part of the survey form, and contact information of researches was added. Data was collected for one month, then subjected to data analysis. 


\section{Data Analysis}

In the data analysis, skewness, and kurtosis values of the data were investigated to determine normal distribution. After determining normal distribution among data, the analysis of the obtained data was made with descriptive statistics, t-test for independent two groups, one-way variance analysis (ANOVA), and correlation test to determine the relationship between dependent variables (scales) $\mathrm{p} \leq 0.05$ significance level was accepted for statistical analysis and interpretation of the data.

\section{Findings}

Table 1: Scale point distribution

\begin{tabular}{lccccccc}
\hline Scale & $\mathrm{N}$ & Min. & Max. & Mean & SD & Skewness & Kurtosis \\
\hline Resilience & 203 & 6.00 & 30.00 & 22.02 & 5.04 & -.511 & -.088 \\
Constant hope total & 203 & 19.00 & 55.00 & 38.46 & 5.39 & -.151 & .532 \\
Alternative sub-dimension & 203 & 11.00 & 32.00 & 25.82 & 4.47 & -.683 & .065 \\
Actuator sub-dimension & 203 & 9.00 & 32.00 & 21.07 & 3.77 & -.186 & .095 \\
\hline
\end{tabular}

Data obtained from students included in the study were analyzed, and points of "Resilience" and "Constant Hope" scale were determined. As shown in Table 1, when points of the two scales were investigated, skewness and kurtosis coefficients indicated that the data has normal distribution. Accordingly, the resilience of students was high, and constant hope was moderate.

Table 2: Gender variable point distribution

\begin{tabular}{lcccccc}
\hline Scale & Gender & $\mathrm{N}$ & Mean & $\mathrm{SD}$ & $\mathrm{t}$ & $\mathrm{p}$ \\
\hline \multirow{2}{*}{ Resilience } & Female & 90 & 22.00 & 5.34 & -.012 & .990 \\
& Male & 112 & 22.23 & 4.82 & & \\
\hline \multirow{2}{*}{ Constant hope } & Female & 90 & 38.62 & 6.02 & .334 & .739 \\
& Male & 112 & 38.36 & 4.88 & & \\
\multirow{2}{*}{ Alternative sub-dimension } & Female & 90 & 25.77 & 4.54 & -.153 & .879 \\
& Male & 112 & 25.87 & 4.45 & & \\
\hline \multirow{2}{*}{ Actuator sub-dimension } & Female & 90 & 21.24 & 4.23 & .507 & .613 \\
& Male & 112 & 20.97 & 3.37 & & \\
\hline
\end{tabular}

Based on the gender variable t-test result, there was no significant difference for female and male students in resilience or constant hope sub-dimensions ( $p>0.05$ ). However, when point averages were considered, the point average of male students was generally higher.

Table 3: Age variable point distribution

\begin{tabular}{|c|c|c|c|c|c|c|c|}
\hline Dependent variables & Age & $\mathrm{N}$ & Mean & SD & $\mathrm{F}$ & $\mathrm{p}$ & Significant \\
\hline \multirow{3}{*}{ Resilience } & $18-20$ & 61 & 20.14 & 5.18 & \multirow{3}{*}{6.57} & \multirow{3}{*}{.002} & \multirow{3}{*}{$\begin{array}{l}18-20 / 21-23 \\
\text { years old }\end{array}$} \\
\hline & $21-23$ & 96 & 22.64 & 4.68 & & & \\
\hline & 24 and more & 46 & 23.21 & 5.02 & & & \\
\hline \multirow{3}{*}{ Constant hope } & $18-20$ & 61 & 38.19 & 5.71 & \multirow{3}{*}{1.33} & \multirow{3}{*}{.265} & \multirow{3}{*}{--- } \\
\hline & $21-23$ & 96 & 38.09 & 5.16 & & & \\
\hline & 24 and more & 46 & 39.60 & 5.40 & & & \\
\hline \multirow{3}{*}{ Alternative sub- } & $18-20$ & 61 & 25.67 & 4.63 & \multirow{3}{*}{.31} & \multirow{3}{*}{.732} & \multirow{3}{*}{---} \\
\hline & $21-23$ & 96 & 25.69 & 4.08 & & & \\
\hline & 24 and more & 46 & 26.28 & 5.08 & & & \\
\hline \multirow{3}{*}{ Actuator sub- } & $18-20$ & 61 & 22.03 & 3.35 & \multirow{3}{*}{4.29} & \multirow{3}{*}{.155} & \multirow{3}{*}{---} \\
\hline & $21-23$ & 96 & 20.30 & 4.20 & & & \\
\hline & 24 and more & 46 & 21.41 & 3.00 & & & \\
\hline
\end{tabular}

In terms of age, there was a significant difference between different age groups for resilience $(p<0.05)$. However, there was no significant difference for constant hope and sub-dimensions among students in different age groups ( $p>0.05$ ). 
Table 4: Relationship between resilience and constant hope

\begin{tabular}{lccccc}
\hline Scales & & Resilience & Constant hope & $\begin{array}{c}\text { Alternative sub- } \\
\text { dimension }\end{array}$ & $\begin{array}{c}\text { Actuator sub- } \\
\text { dimension }\end{array}$ \\
\hline Resilience & $\mathrm{r}$ & 1 & $.510^{* *}$ & $.359^{* *}$ & -.044 \\
& $\mathrm{p}$ & & .000 & .000 & .531 \\
& $\mathrm{~N}$ & 203 & 203 & 203 & 203 \\
\hline Constant hope & $\mathrm{r}$ & $.510^{* *}$ & 1 & $.660^{* *}$ & $.731^{* *}$ \\
& $\mathrm{p}$ & .000 & & .000 & .000 \\
\hline Alternative sub- & $\mathrm{N}$ & 203 & 203 & 203 & 203 \\
dimension & $\mathrm{r}$ & $.359^{* *}$ & $.660^{* *}$ & 1 & $.407^{* *}$ \\
& $\mathrm{p}$ & .000 & .000 & 200 & .000 \\
\hline Actuator sub- & $\mathrm{N}$ &. .044 & $.731^{* *}$ & $.407^{* *}$ & 1 \\
dimension & $\mathrm{p}$ & .531 & .000 & .000 & 203 \\
& $\mathrm{~N}$ & 203 & 203 & 203 & 203 \\
\hline
\end{tabular}

Correlation analysis indicated that there was a significant difference between resilience and constant hope scale points. The relationship between resilience and constant hope was positive and at moderate.

\section{Discussion}

\section{Discussion according to resilience}

In this study, the gender variable indicated that there was no significant difference between female and male students in terms of resilience. This finding has shown that gender has no effect on resilience. Karairmak and Guloglu (2014) determined no significant difference between female and male adults in terms of resilience. Tumlu and Recepoglu (2013) \& Yagmur and Turkmen (2017) indicated there was no difference between female and male individuals in terms of resilience. Studies in the literature supported the results of this study in terms of gender variable. However, Gungormus et al. (2015); Cole et al. (2004); Tasgin et al. (2017); Gundas and Kocak (2015); Oktan et al. (2015); Kocak et al. (2017) determined significant difference between female and male individual in terms of resilience. The results of this study fail to comply with such literature findings.

When examined in terms of another variable, there was a significant difference between different age groups for resilience. This finding indicates that there is a relationship between resilience and age. Cutuk et al. (2017) worked with judo sports players and found significant relationship between resilience and age. This result was in line with age variable result of this study. However, Gungormus et al. (2015) found no significant difference between resilience and students in different age groups. Sezgin (2016) worked on students and Tumlu and Recepoglu (2013) worked with academic personnel and found that there was no significant difference between resilience and age variable.

\section{Discussion according to constant hope levels}

According to the gender variable, there was no significant difference between female and male students for constant hope levels. These findings were in line with Atik and Atik (2017); Feldman and Snyder, 2005; Snyder et al., 1991; Snyder et al., 1996; Kemer and Atik (2005); Atik and Kemer (2009); Aydin (2010); Aydogan (2010), while this finding was against Kemer and Atik (2012). There was no significant difference in the constant hope levels of students for age.

\section{Discussion according to relationship between resilience and constant hope levels}

It is clear that resilience and constant hope scale points of students were significant. The relationship between resilience and constant hope was positive and at moderate level. Aydin (2010) worked on university students and determined that there was positive and moderate relationship between resilience and hope levels. This finding supported the results of dependent variables in this study.

\section{Conclusion}

In this study, data collected from students were analyzed. It was found that this data had normal distribution. In this sense, skewness and kurtosis coefficients of Resilience and Constant Hope scales had normal distribution. Based on the obtained results, it was determined that resilience of students was high, and constant hope was moderate.

Based on gender variable result, there was no significant difference for female and male students for resilience and constant hope sub-dimensions. This insignificant result indicated that female and male students has similar tendency in terms of resilience. Additionally, in terms of constant hope, male and female students showed similar trend. It could be commented that similar life conditions and life styles of female and male students may have led to these results. Kemer and Atik (2012) based gender differences on child rearing styles in Turkey and social norms and found that male students had higher hope levels than female students. 
Another result indicated that while there was significant difference for age variable for resilience, there was no significant difference of constant hope levels. High resilience of students in 24 and higher age category could be explained by the fact that maturity increases with age, development of analytic thinking, increased auto-control, and increased comparative abilities.

Correlation analysis indicated that there was a significant difference between resilience and constant hope scale points. It was understood that the relationship between resilience and constant hope was positive and at moderate level. As resilience increases, the level of constant hope is constantly increasing at the middle level.

\section{Recommendations}

Future studies could work on a larger sample. Additionally, students from different departments should be added to increase the diversity of the studies. Since resilience and constant hope concepts are limited to physical education and sports areas, the number of similar results could be increased. Increasing the number of participants in the future studies could increase the reliability of these studies. Additionally, this subject could be investigated with qualitative aspects for new dimension.

\section{References}

Atik, G., \& Atik, Z. E. (2017). Lise ogrencilerinin umut duzeylerinin yordanmasi: Akademik ozyeterlik ve problem cozmenin rolu [Predicting Hope Levels of High School Students: The Role of Academic Self-Efficacy and Problem Solving]. Education and Science, 42(190), 157-169.

Atik, G., \& Kemer, G. (2009). Cocuklarda Umut Olcegi'nin Psikometrik Ozellikleri: Gecerlik ve Guvenirlik Calismasi [Psychometric Properties of Children's Hope Scale: Validity and Reliability Study]. Elementary Education Online, 8(2), 379-390.

Aydin, B. (2010). Universite ogrencilerinin duygusal zekâ ve umut duzeyleri ile psikolojik saglamlıkları arasindaki iliskinin incelenmesi [the investigation of the relationship between university students 'emotional intelligence and hope levels and psychological stability] (Unpublished Master's Thesis). Karadeniz Technical University, Trabzon.

Aydogan, S. (2010).Ilkogretim 2. Kademe Ogrencilerinin Umut ve Benlik Saygisi Duzeylerinin Bazi Degiskenler Acisindan Incelenmesi [Investıgatıon of Elementary School Second Grade Students' Hope and Self-Esteem Levels According to Some Variables] (Unpublished Master's Thesis). Selcuk University, Konya.

Aydogdu, T. (2013). Baglanma Stilleri, Basa Cikma Stratejileri ile Psikolojik Dayaniklilik Arasindaki Iliskinin Incelenmesi [Attachment styles, coping strategies between psychological hardiness examining of the relationships] (Unpublished Master's Thesis). Gazi University, Ankara.

Bailey, T. C., \& Snyder, C. R. (2007). Satisfaction with life and hope: a look at age and marital status. The Psychological Record, 57, 233-240.

Bloch, E. (2007). Umut ilkesi [Hope principle]. Vol. 1 (Trans. T. Bora). Istanbul: Iletisim.

Cacioppo, J.T., Gardner, W.L., \& Berntson, G.G. (1999). The affect system has parallel and integrative processing components: Form follows function. Journal of Personality and Social Psychology, 76, 839-855.

Carver, C. S., \& Scheier, M. F. (1990). Origins and functions of positive and negative affect: A control process view. Psychological Review, 97(1), 19-35.

Cole, M., Field, H., \& Harris S. (2004). Student learning motivation and psychological hardiness: Interactive effects on students' reaction to a management class. Academy of Management Learning and Education, 3(1), 64-85.

Cole, B. P. (2008). Correlations between trait and academic measure of hope and the inventory on learning climate and student well-being (Unpublished Master's thesis). University of Kansas, USA.

Cutuk, S., Beyleroglu, M., Hazar, M., Cutuk, Z. A., \& Bezci, S. (2017). Judo sporcularinin psikolojik dayaniklilik duzeyleri ile kaygi duzeyleri arasindaki iliskinin incelenmesi [the investigation of the relationship between psychological resilience levels and anxiety levels of judo athletes]. Nigde University Journal of Physical Education and Sports Science, 11(1), 109-117.

Dogan, T. (2015). Kısa Psikolojik Saglamlık Olcegi'nin Turkce uyarlamasi: Gecerlik ve guvenirlik calısması [Adaptation of the Brief Resilience Scale into Turkish: A validity and reliability study]. The Journal of Happiness \& WellBeing, 3(1), 93-102. 
Duran, S., \& Unsal, G. (2014). Cankiri ilindeki sehit aileleri ve malul gazilerin psikolojik dayanıklılı ve depresif durumlarının belirlenmesi [An evaluation of psychiological endurance and deppresive situation of veterans and martyr's relatives in cankiri province]. Acibadem University Health Sciences Journal, 5(2), 158-163.

Feldman, D. B., \& Snyder, C. R. (2005). Hope and the meaningful life: Theoretical and emprical associations between goal-directed thinking and life meaning. Journal of Social and Clinical Psychology, 24(3), 401-421.

Frankl, V. E. (2000). Insanin anlam arayisi [Human search for meaning]( $7^{\text {th }}$ Ed.). (Trans. S. Budak). Ankara: Oteki yayinlari.

Fraser, M. W., Richman, J. M., \& Galinsky, M. J. (1999). Risk, protection and resilience: toward a conceptual framework for social work practice. Social Work Research, 23(3), 131-143.

Fredrickson, B. L. (2001). The role of positive emotions in positive psychology: The broaden and build theory of positive emotions. American Psychologist, 56(3), 218-226.

Gilligan, R. (1999). Enhancing the resilience of children and young people in public care by mentoring their talents and interests. Child \& Family Social Work, 4(3), 187-196.

Guloglu, B., \& Karairmak, O. (2010). Universite ogrencilerinde yalnizligin yordayicisi olarak benlik saygisi ve psikolojik saglamlı [Self-esteem and Resilience as the Predictors of Loneliness among University Students]. Journal of Ege Education, 11(2), 73-88.

Gundas, A., \& Kocak, R. (2015). Lise ogrencilerinde psikolojik saglamligin yordayicisi olarak benlik kurgusu [The Role of Self-Construals as The Predictors of Psychological Resilience of High School Students]. The Journal of International Social Research, 8(41), 795-802.

Gungormus, K., Okanli, A., \& Kocabeyoglu, T. (2015). Hemsirelik Ogrencilerinin Psikolojik Dayanikliliklari ve Etkileyen Faktorler [Factors Influencing Resilience in Nursing Students]. Journal of Psychiatric Nursing, 6(1), 9-14.

Karairmak, O., \& Guloglu, B. (2014). Deprem deneyimi yasamis yetiskinlerde baglanma modeline gore psikolojik saglamligin aciklanmasi [The Explanatıon of Resilıence Withın Attachment Model Among Adults With Earthquake Experience]. Cukurova university faculty of education journal, 43(2), 1-18.

Kemer, G., \& Atik, G. (2005). Kirsal ve il merkezinde yasayan lise ogrencilerinin umut duzeylerinin aileden algilanan sosyal destek duzeyine gore karsilastirilmasi [Comparison of hope levels of high school students living in rural and province center by their social support levels]. MU Ataturk Education Faculty Journal of Educational Sciences, 21, 161-168.

Kemer, G., \& Atik, G. (2012). Hope and social support in high school students from urban and rural areas of Ankara, Turkey. Journal of Happiness Studies, 13(5), 901-911.

Kocak, M., Ozbas, A. A., \& Gurhan, N. (2017). Beden egitimi ve spor ogrencilerinin psikolojik saglamlik ve oz yeterlik duzeyinin belirlenmesi [Identification of psychological resilience and self-efficacy levels of physical educationsport students]. Nigde University Journal of Physical Education and Sports Science, 11(2), 129-135.

Martinek, T. J., \& Hellison, D. R. (1997). Fostering resiliency in undeserved youth through physical activity. Quest, 49(1), 34-49.

Masten, A. S. (2001). Ordinary magic: Resilience processes in development. American Psychologist, 56(3), $227-238$.

Miller, J. F. (2007). Hope: A construct central to Nursing. Nursing Forum, 42(1), 12-19.

Oktan, V., Odaci, H., \& Celik, C.B. (2015). Psikolojik dogum sirasinin psikolojik saglamligin yordanmasindaki rolunun incelenmesi [Investigating the Role of Psychological Birth Order in Predicting Resilience]. Abant Izzet Baysal Universitesi Egitim Fakultesi Dergisi, 14(1), 140-152.

Ogulmus, S. (2001). Bir Kisilik Ozelligi Olarak Yilmazlik [Resiliency as a personality trait]. I. Ulusal Cocuk ve Suc Sempozyumu: Nedenler ve Onleme Calismalari [Ist National Child and Crime Symposium: Causes and Prevention Studies], 29-30 March, Ankara.

Onder, A., \& Gulay, H. (2008). Ilkogretim 8. Sinif ogrencilerinin psikolojik saglamliginin cesitli degiskenler acisindan incelenmesi [Resilience of 8 grade students in relation to various variables]. Buca Faculty of Education Journal, 23, 192-197.

Sagkal, A. S., \& Turnuklu, A. (2017). Baris egitimi programinin lise ogrencilerinin oznel iyi olus ve umut duzeyleri uzerindeki etkileri [The effects of peace education program on high school students' subjective well-being and levels of hope]. Turkish Psychological Counseling and Guidance Journal, 7(47), 69-85. 
Sezgin, K. (2016). Universite Ogrencilerinin Psikolojik Saglamlik ve Dindarlik Duzeylerinin Incelenmesi (Dicle Universitesi Ornegi) [Investigation of psychological stability and level of levels of university students Dicle University example] (Unpublished Master's Thesis). Dicle University, Diyarbakir.

Smith, B. W., Dalen, J., Wiggins, K., Tooley, E., Christopher, P., \& Jennifer Bernard, J. (2008). The brief resilience scale: Assessing the ability to bounce back. International Journal of Behavioral Medicine, 15(3), 194-200.

Snyder, C. R. (2002). Hope theory: Rainbows in the mind. Psychological Inquiry, 13(4), 249-275.

Snyder, C. R., Harris, C., Anderson, J. R., Holleran, S. A., Irving, L. M., Sigmon, S. T., \& Harney, P. (1991). The will and the ways: Development and validation of an individual-differences measure of hope. Journal of Personality and Social Psychology, 60(4), 570-585.

Snyder, C. R., La Pointe, A. B., Crowson, J. J., \& Early, S. (1998). Preferences of high and low-hope people for selfreferential input. Cognition \& Emotion, 12(6), 807-823.

Snyder, C. R., Sympson, S. C., Basco, F. C., Borders, T. F., Babyak, M. A. and Higgins, T. F. (1996). Development and validation of the State Hope Scale. Journal of Personality and Social Psychology, 70(2), 321-335.

Staats, S., \& Stassen, M. A. (1985). Hope: An affective cognition. Social Indicators Research, 17(3), $235-242$.

Staudinger, U, Marsiske, M., \& Baltes, P. B. (1993). Resilience and levels of reserve capacity in later adulthood: Perspectives from life-span theory. Development and Psychopathology, 5(4), 541-566.

Tasgin, O., Bozgeyikli, H., \& Bogazliyan, E.E. (2017). Universiteli ergenlerin issizlik kaygilari ile psikolojik dayanikliliklari arasindaki iliski [The relationship between university students' unemployment anxiety and their psychological resillience]. Labor and Society Journal, 6(16), 551-557.

Tarhan, S., \& Bacanli, H. (2015). Surekli Umut Olcegi'nin Turkce'ye uyarlanmasi: Gecerlik ve guvenirlik calismasi [Adaptation of Dispositional Hope Scale into Turkish: Validity and reliability study]. The Journal of Happiness \& Well-Being, 3(1), 1-14

Terzi, S. (2005). Iyi olmaya iliskin psikolojik dayaniklilik modeli [Psychological well-being model of goodness] (Unpublished doctoral dissertation). Gazi University, Ankara.

Terzi, S. (2008). Universite ogrencilerinin kendini toparlama gucunun icsel koruyucu faktorlerle iliskisi [the relationships between resilience and internal protective factors in university students]. Hacettepe University Journal of Education, 35(35), 297-306.

Tsukasa, K., \& Snyder, C. R. (2005). The relationship between hope and subjective well-being: Reliability and validity of the dispositional hope scale, Japanese version. Japanese Journal of Psychology, 76(3) 227-234.

Tumlu, G. U., \& Recepoglu, E. (2013). Universite akademik personelinin psikolojik dayaniklilik ve yasam doyumu arasindaki iliski [The Relationship between Psychological Resilience and Life Satisfaction of University Academic Staff]. Journal of Higher Education and Science, 3(3), 205-213.

Uz Bas, A., \& Yurdabakan, I. (2017). Psikolojik saglamlik ve okul ikliminin ortaokul ogrencilerinin yasam doyumunu yordama gucu [The Predictive Value of Resilience and School Climate in Life Satisfaction among Middle School Students]. Mehmet Akif Ersoy University Journal of Education Faculty, 1(41), 202-214.

Yagmur, T., \& Turkmen, S. N. (2017). Ruhsal hastaligi olan hastalara bakim veren aile uyelerinde algilanan stres ve psikolojik dayaniklilik [Perceived Stress and Psychological Durability in Patients with Mental Illness]. Manisa CBU Journal of Institute of Health Science, 4(1), 542-548.

Yu, X., \& Zhang, J. (2007). Factor analysis and psychometric evaluation of the Connor-Davidson Resilience Scale (CDRISC) with Chinese people. Social Behavior and Personality: An International Journal, 35(1), 19-30.

Zournazi, M. (2004). Umut degisim icin yeni felsefeler (Trans. U. Abaci) [New philosophies for hope change]. Istanbul: Literatur. 